\title{
Retraction Note to: The formation mechanism of heavy pollution weather based on abnormal flow detection and the impact of big data sports training
}

\author{
Shen $\mathrm{Cao}^{1} \cdot$ Lina Ren ${ }^{1}$
}

Published online: 9 November 2021

(c) Saudi Society for Geosciences 2021

Retraction Note to: Arabian Journal of Geosciences (2021) 14: 1590

https://doi.org/10.1007/s12517-021-07968-6

The Editor-in-Chief and the Publisher have retracted this article because the content of this article is nonsensical. The peer review process was not carried out in accordance with the Publisher's peer review policy. Author Shen Cao has not responded to correspondence regarding this retraction. The publisher has not been able to obtain a current email address for author Lina Ren.

The original article can be found online at https://doi.org/10.1007/ s12517-021-07968-6.

Shen Cao

nescafe2021@163.com

1 Hebei Institute of Communications, Shijiazhuang 050000,

Hebei, China 